\title{
Water Resources and Management under Increasing Urban Demography: A Kenyan Perspective-A Review
}

\author{
Deziline Adhiambo Ondigo ${ }^{*}$, Agnes Mumo Kavoo ${ }^{2}$, Jeremiah Kebwaro' \\ ${ }^{1}$ Department of Physical Sciences, Karatina University, Karatina, Kenya \\ ${ }^{2}$ Department of Horticulture, Jomo Kenyatta University of Agriculture and Technology, Nairobi, Kenya \\ Email: *dondigo@karu.ac.ke
}

How to cite this paper: Ondigo, D.A., Kavoo, A.M. and Kebwaro, J. (2018) Water Resources and Management under Increasing Urban Demography: A Kenyan Perspective-A Review. Journal of Water Resource and Protection, 10, 919-938. https://doi.org/10.4236/jwarp.2018.109054

Received: August 7, 2018

Accepted: September 24, 2018

Published: September 27, 2018

Copyright ( $) 2018$ by authors and Scientific Research Publishing Inc. This work is licensed under the Creative Commons Attribution International License (CC BY 4.0).

http://creativecommons.org/licenses/by/4.0/

\begin{abstract}
The United Nations classifies Kenya as a water-scarce country since it has less than $1000 \mathrm{~m}^{3}$ per capita of renewable freshwater supplies. Numerous factors including global warming, contamination of drinking water, and a lack of investment in water resources have aggravated the water crisis in Kenya. Estimates indicate that only about $56 \%$ of its population has access to safe water supply. Like many developing countries, Kenya recognizes the crucial role of water in realizing its development goals. Its economic performance and poverty reduction are critically dependent on clean water availability for agriculture, industrialization, energy production and tourism among others. Similar to most developing countries, Kenya suffers from lack of human, monetary and institutional capabilities to efficiently provide clean and sufficient water to its citizens. The water shortage in the major cities is acute and chronic and has continued to worsen with increasing urbanization, water pollution and encroachment of water catchment areas by humans and invasive plant species. Despite the water challenges facing the urban populations, Kenya possesses sufficient water resources to meet demand if the available resources are properly managed. Several initiatives are being put in place in Kenya to mitigate the water challenges and protect water resources in Kenya. These include enacting of water policies to protect water catchment areas, reduce pollution and enhance access to clean water.
\end{abstract}

\section{Keywords}

Kenya, Urbanization, Water Resource Crisis, Water Act and Policy, Water Kiosks 


\section{Introduction}

Kenya is located in Eastern part of Africa. It covers an area of $581,309 \mathrm{~km}^{2}$ and has a population of 45 million people [1]. Kenya shares about $50 \%$ of her water resources i.e. rivers, lakes, and aquifers with her neighbors in East Africa, even though it has one of the lowest natural water replenishment rates of $647 \mathrm{~m}^{3}$ per capita per annum (Figure 1). It is home to 10 rivers in the following basins: River Omo Basin between Kenya and Ethiopia; Mara River Basin between Kenya and Tanzania; Rivers Sio, Malaba, and Malakisi Basin between Kenya and Uganda and the Merti aquifer in north eastern part of Kenya extending into Somalia [2].

The United Nations classifies Kenya as a water-scarce country since it has less than $1000 \mathrm{~m}^{3}$ per capita of renewable freshwater supplies [3]. Eighty percent of Kenya is made up of semi-arid land and only $20 \%$ is arable. Estimates indicate that only about $56 \%$ of its population has access to safe water supply. Numerous factors such as global warming (which has led to recurrent and severe droughts as well as floods), the contamination of drinking water, and a lack of investment in water resources have aggravated the water crisis.

Like all other nations, Kenya recognizes the crucial role of water in realizing its development goals. Its economic performance and poverty reduction are critically dependent on clean water availability. Water is an essential input in Kenya's diverse economic activities including agriculture, industrialization, energy production and tourism among others. Hence access to safe and sufficient amount of water is necessary for the well-being of the population.

Kenya is a home to three major cities namely Nairobi, Mombasa and Kisumu. Kenya's capital city, Nairobi was founded as a railway station in the late $17^{\text {th }}$

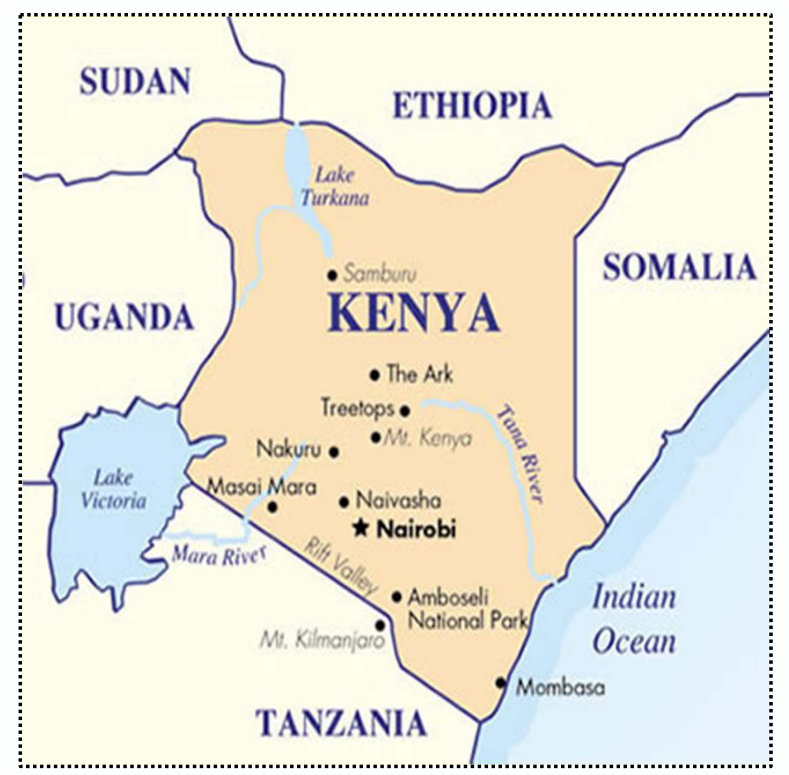

Figure 1. Geographical location of Kenya in relation to the main water surface water sources. 
century. It covers an area of $696 \mathrm{~km}^{2}$ and holds a population of about 3.3 million people [4]. The city accounts for $60 \%$ of Kenya's Gross Domestic Product [5].

Nairobi is known to experience severe water shortage since the demand exceeds the supply by about $200,000 \mathrm{~m}^{3}$ per day [6]. Currently, only about half of the city's population have access to piped water out of which, only $40 \%$ receive water on a 24-hour basis [7]. According to the Nairobi City Water and Sewerage Company (NCWSC), the estimated demand for the residents of Nairobi in the year 2010 was $650,000 \mathrm{~m}^{3}$ per day while the supply stood at only $482,940 \mathrm{~m}^{3}$ per day [8].

Mombasa is the second largest city situated on the Kenyan coast [9]. In 2016 its population was estimated to be about 1.2 million [10]. Administratively, it is the capital of Mombasa County. Although more than $80 \%$ of the population is reported to have access to an improved water source because they receive water from kiosks, only about $15 \%$ of the people have access to piped water supply. Like in the case of Nairobi, most parts of Mombasa receive water once in three or four days and other parts hardly ever receive due to low water pressure. The sources supply on average $45,000 \mathrm{~m}^{3}$ of water daily against an estimated demand of $150,000 \mathrm{~m}^{3}$ which is expected to rise to $200,000 \mathrm{~m}^{3}$ within a period of 10 years [11]. Generally, Mombasa is considered as a very dry city which has only four remote freshwater sources namely; Baricho in Sabaki Well field, the Marere Water Works, Mzima Springs and Tiwi Boreholes [12].

With an estimated population of 520,000 [13], Kenya's third largest city, Kisumu serves as a trading and transportation hub for the Great Lakes region. Kisumu water and sewerage company ltd (KIWASCO) abstracts water from two sources; River Kibos and Lake Victoria. In 2007 the projected water production was $18,000 \mathrm{~m}^{3}$, against an estimated demand of $48,000 \mathrm{~m}^{3}$ [14] despite sitting on the shores of Lake Victoria which is the second largest fresh water lake in the world. This represented a big shortfall which had to be met by other sources [15].

Similar to many cities in the world, water production in Kisumu does not match its rapid population growth. In 2008, only about $52 \%$ of Kisumu residents were reported to have access to piped water which was delivered to residences, and 13 percent relied on water drawn from shallow wells/boreholes or rain [16]. Hence only $65 \%$ of its residents had access to an improved water source, while the rest used unimproved water sources such as open wells/springs, streams and ponds [16].

The greatest challenge in Kisumu city is in the informal settlements where, the water supply is often unreliable and insufficient. These residents obtain water from individual connections, public tap connections, boreholes, springs and water vendors which remain unmonitored. In these three cities, safety of tap water is not entirely guaranteed since tap water may be polluted and harmful to human health. As such use of bottled water and water dispensers have become common. 


\section{The Challenges Facing the Water Sector in Major Cities in Kenyan}

Similar to most developing countries, Kenya suffers from lack of human, monetary and institutional capabilities to efficiently provide clean and sufficient water to its citizens. The water shortage in the major cities is acute and chronic. More often than not notices of interruption of water is the norm in urban settings (Figure 2(a) and Figure 2(b)).

Water shortage could get worse in the future owing to a number of reasons such as 1) increasing demand due to rapid urbanization, 2) poor management of water services, 3) continuous degradation of water catchment areas 4) erratic climatic conditions 5) old and dilapidated water infrastructure; and 6) incompetence of the water treatment companies.

\subsection{Growing Populations and Urbanization}

Kenya, like many other developing countries in Africa, is experiencing rapid urbanization [17]. In 1948 its population was estimated at 5.4 million people and in the year 2009 it had hit 39 million people [1]. United Nations estimates indicated that Kenya's urban population will increase to 38 million by the year 2030 which would account for 62.7 percent of the national population [18]. Urbanization does not only mean a swell in population but also the increase in the area in need of improved services. Rural-to-urban migration in Sub-Saharan African countries constitutes the single most important cause of the rapid growth of the urban population. The growing population (Figure 3(a) and Figure 3(b)) continues to exert pressure on the available water resources and this has resulted in reduction of per capita water availability.

The growth of the country's urban population and rapid urbanization of its rural areas continue as a major demographic trend. It is projected that $70 \%$ of the world's population will live in urban areas by 2050 [6] [20]. We typically live on an urban world since it is estimated that more than half of the world's population lives in cities. The growing population continues to increase the demand for water for domestic, industrial and agricultural uses.

There are three main causes for rapid urbanization currently being witnessed in Africa: 1) movement of people from rural areas to urban centers; 2) population increase among urban residents especially when economic opportunities expand to previously rural neighborhoods and, 3) development of previously rural areas to urban areas due to increased economic activities. It is not easy to exactly define what an urban setting is, but it is largely accepted that the term could be determined based on locality, population size, and percentage of non-agricultural activities.

Urbanization is among the most significant factors that have created great pressures on environmental resources such as water. Over the last few years urbanization of rural areas has substantially increased as agriculture, many previously traditional local services, and small-scale industries give way to modern 


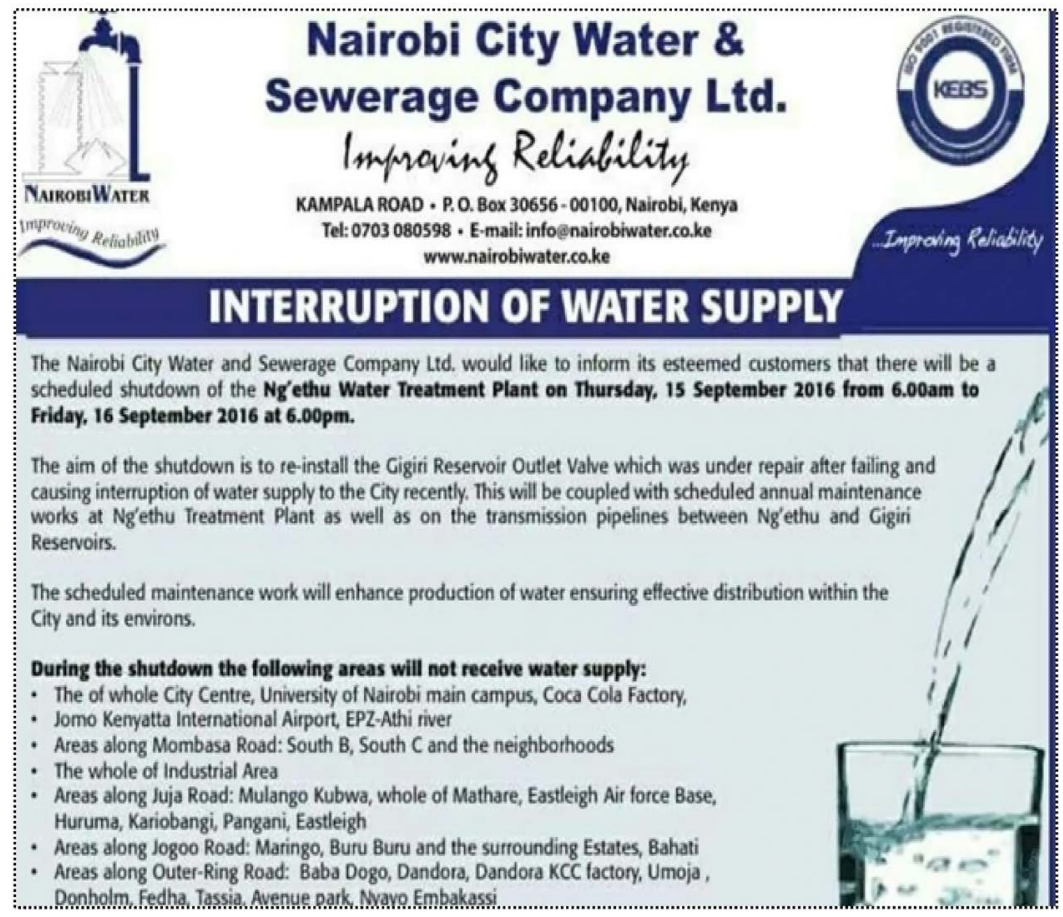

(a)

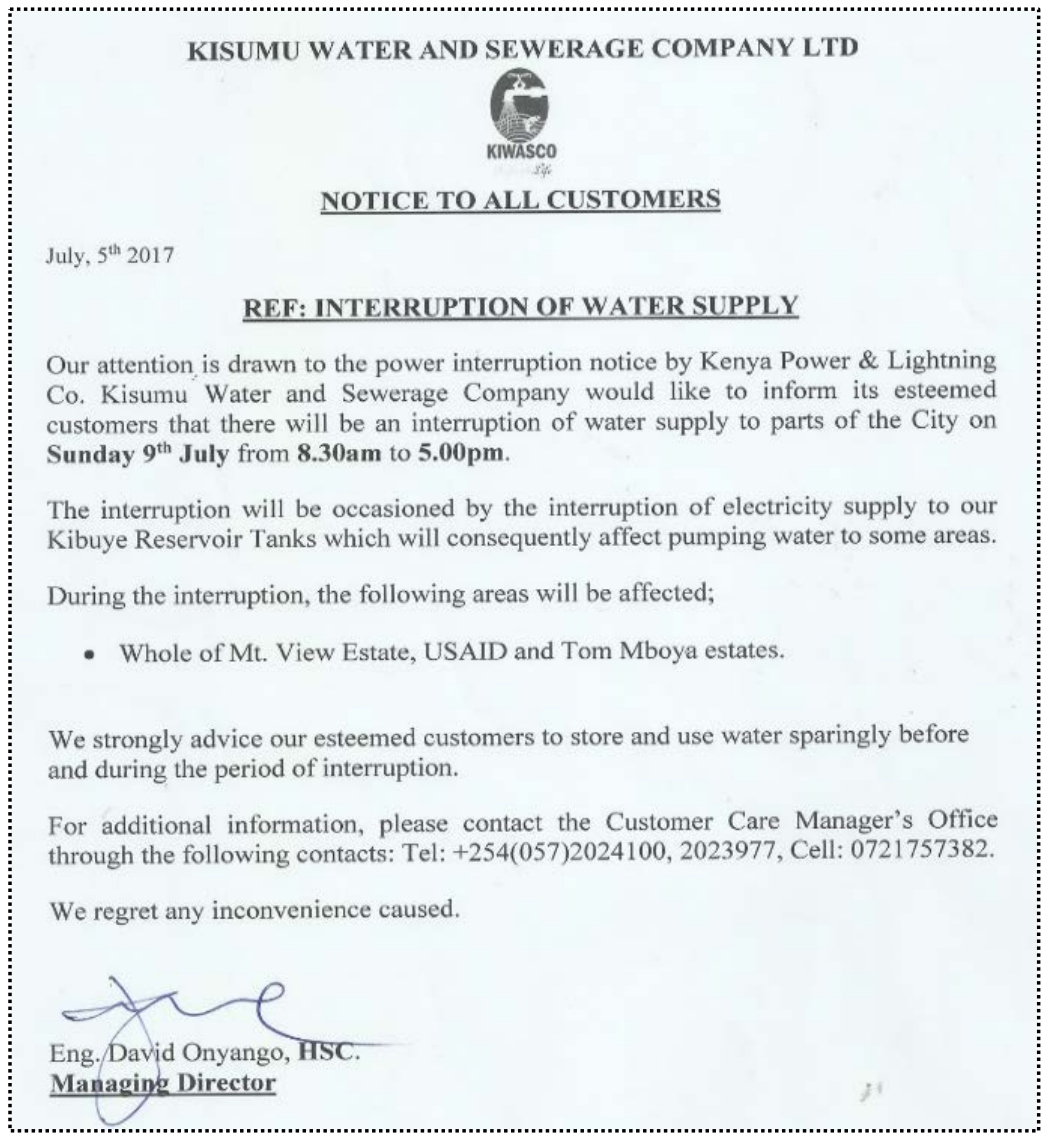

(b)

Figure 2. (a) Notice of disruption of water supply by Nairobi City Water Company; (b) Notice of disruption of water supply by Kisumu Water and Sewerage Company. 


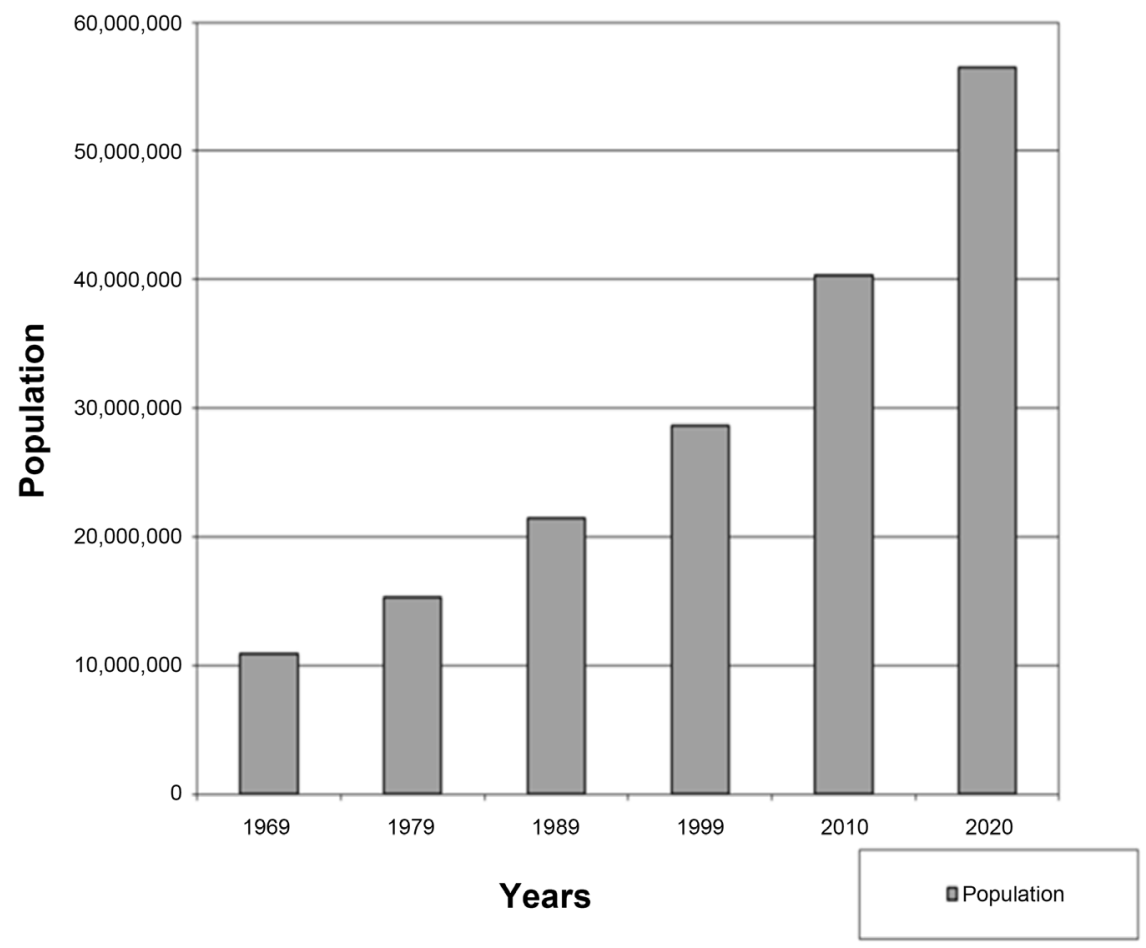

(a)

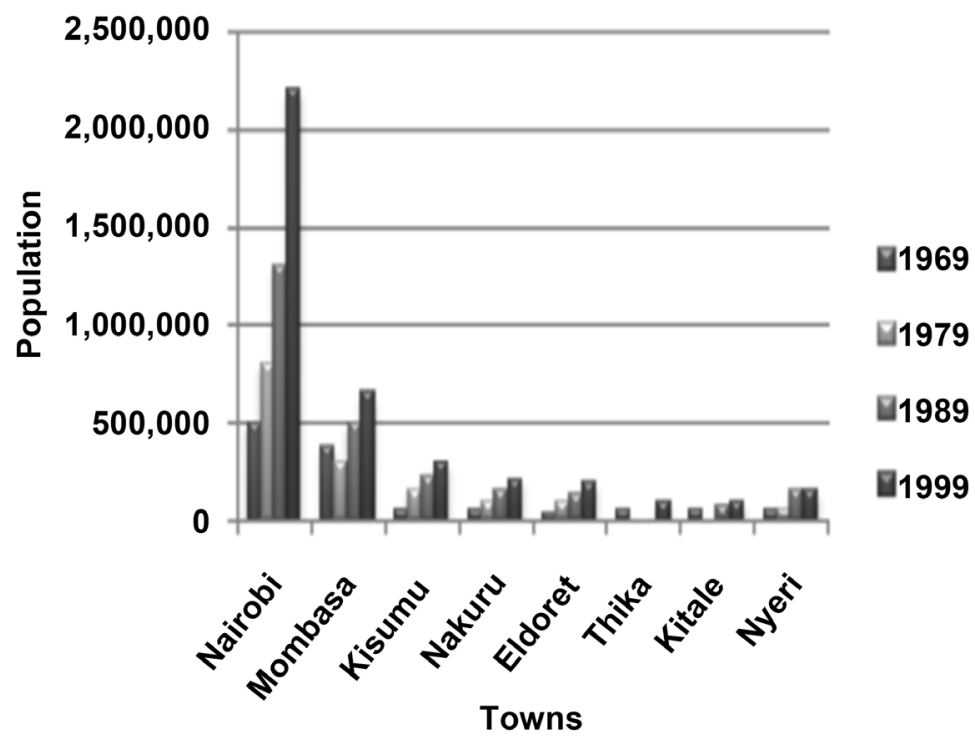

(b)

Figure 3. (a) Projected population growth trend (source: CBS Population Census 1999); (b) Kenya's urban population growth trend during the period 1969-1999 [19].

industries. Although there are numerous social and economic benefits of urbanization, it comes with numerous environmental ills. It has directly affected water availability and quality through increased demand and pollution resulting from its many applications.

Like many urbanizing worlds, lack of access to clean water is wide spread 
among the urban population in Kenya. Rapid urbanization has left Kenyan cities unable to cope with the huge demand for clean and sufficient supply of water.

\subsection{Contamination of Available Water}

Available water sources are frequently affected by pollution. Water quality can be affected by various pollutants e.g. chemical, microbiological, thermal pollutants among others [21] [22] [23]. Chemical contamination can result from presence of excess nutrients, acidification, salinity, heavy metals, Persistent Organic Pollutants (POPs) and changes in sediment loads. Microbiological contamination may result from the presence of either bacteria, viruses or protozoa in water. Reports indicate that industries at $32.5 \%$ and agriculture at $14 \%$ are the sectors that contribute most to economic development of any population [24]. In contrast, $80 \%$ of water contamination originate from these two important sectors.

Most problems affecting water quality are instigated by agricultural practices, industrialization, mining activities and open sewage lines which run parallel to "the water network" [25]. The lack of proper management of liquid and solid wastes results in these wastes being deposited directly into water bodies (Figure 4 ), and this contributes to the vicious circle of water destruction.

In fact the most visible solid waste is the plastic bags that litter most of the areas around these water bodies and various parts of the central business districts. On the other hand growth and development of agriculture in Kenya has led to increase in the use of fertilizers. Agrochemicals eventually find their way into water bodies causing immense pollution. Furthermore, most industrial and county government's sewage plants discharge partially treated or completely untreated effluents into surface water sources, which often contain high levels of toxic substances. These and other pollutants from domestic use continue to cause environmental ills.

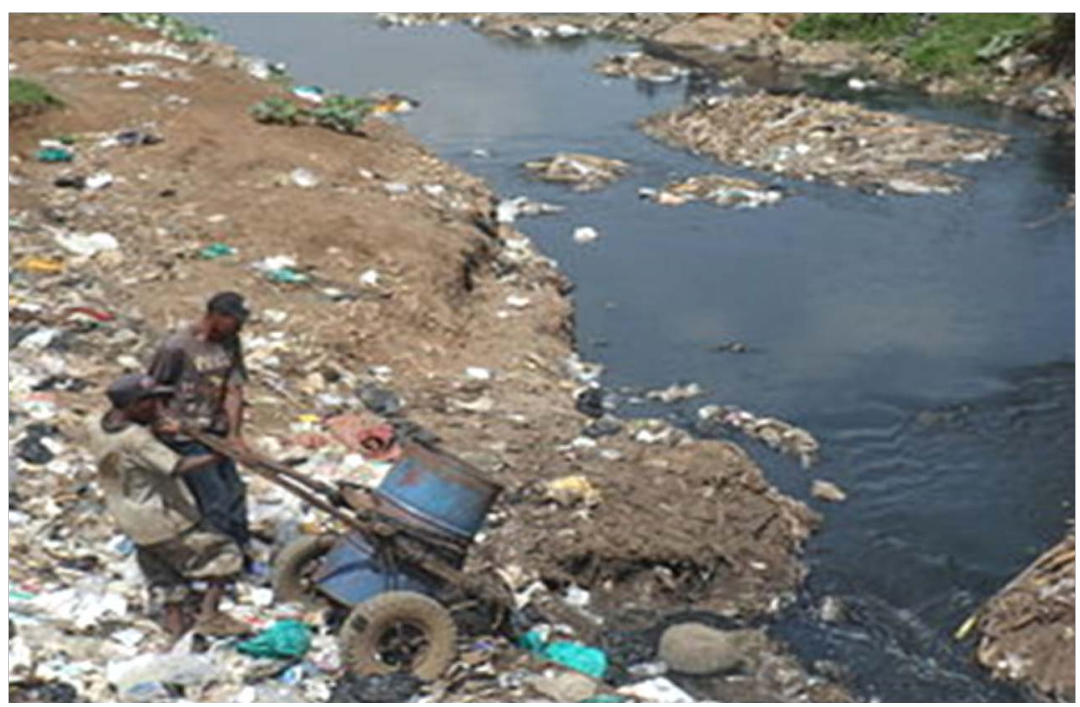

Figure 4. Heavily polluted Nairobi River. 
Water quality in Kenya has been compounded by lack of ability of the service providers and national institutions charged with the responsibility to maintain and provide clean water to the residents. Most Kenyans living in informal urban settlements do not have access to clean water and this often causes multiple disease outbreaks that affects their health and livelihoods. In addition, flooding, high leakage in the water service lines (Figure 5(a)), old and dilapidated infrastructure and illegal connections further strain the availability of existing clean water supply.

According to a past report a section of residents in Nairobi who receive piped water complained that the water was highly contaminated, had a bad smell, unusual color and visible particles [26]. This could be as a result of the old, rusty pipes that often break and water gets polluted before reaching the taps Figure 5(b)). Due to high leakage in the water channels, treated water is sometimes re-contaminated before it reaches the users. In 2009/2010, the Water Sector

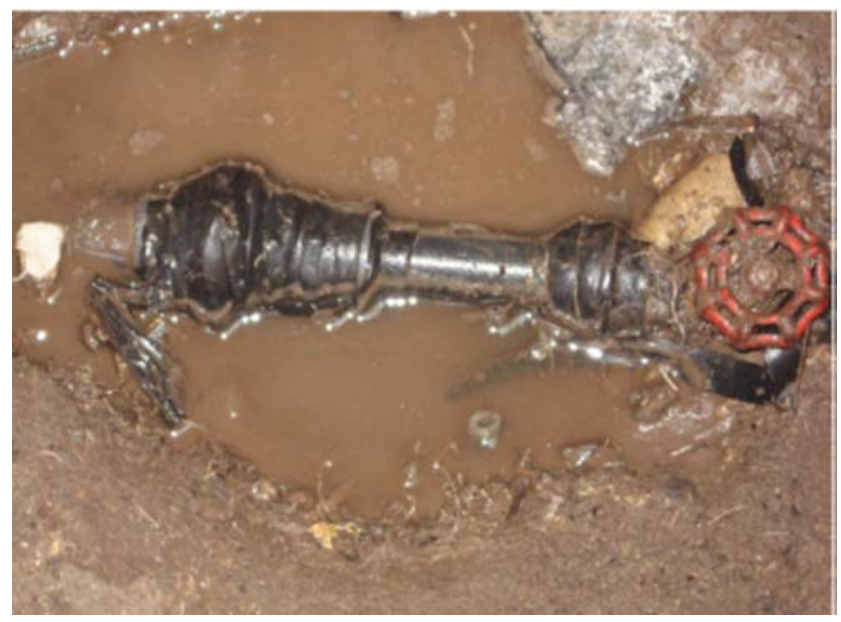

(a)

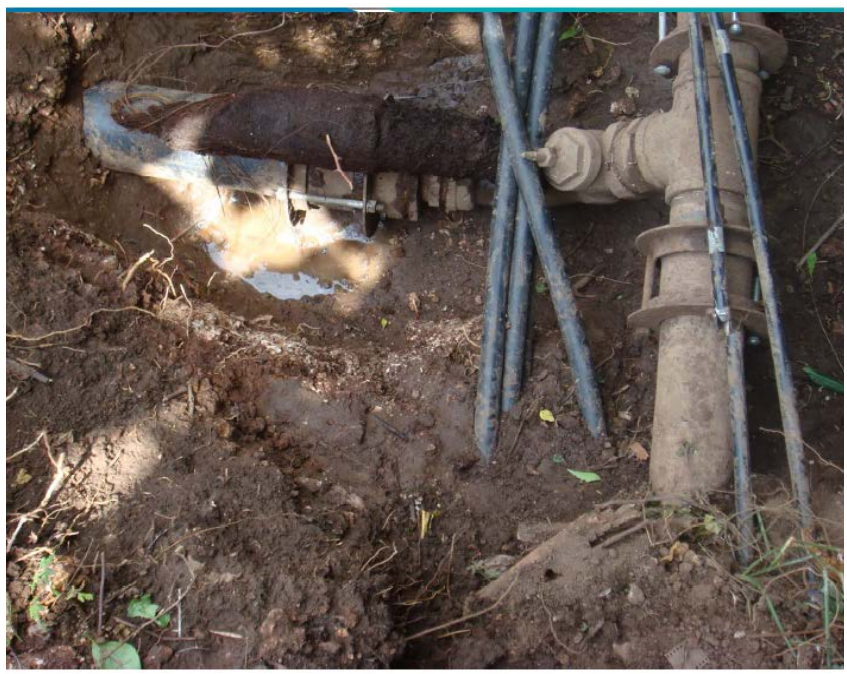

(b)

Figure 5. (a) Delapitated water infrastructure; (b) A leaking water pipe. 
Regulatory Board (WSRB), reported that only $76 \%$ of drinking water samples conformed to standards for bacterial quality, a level considered unacceptable by the regulator [26]. Likewise, water can be contaminated as a result of pipe bursts [27] that occur very frequently.

\subsection{Encroachment of Water Catchment Areas and “Kenya's Water Towers"}

In the year 1963, Kenya had $12 \%$ forest cover, this has since reduced and the present forest cover of $6.99 \%$ of the land area of Kenya is still below the Kenyan constitutional requirement of $10 \%$ [28].

Kenya's forests support the five main catchment areas occupying a total of 903,962 hectares namely: Mount Kenya (199,558 ha), Aberdare Ranges (103,315 ha), Cherangani Hills (128,000 ha), Mt. Elgon (73,089 ha), and Mau Forest Complex which is the most important water catchment measuring 400,000 ha (Figure 6). These important sources are often referred to as "Kenya's water towers" as they form the upper catchment of all except one main river in Kenya. These water catchment areas with a coverage of only $2 \%$ of the total land area have and continue to provide important services to the economy of Kenya as well as supporting transboundary water bodies, underlying their regional and international importance [11].

Nairobi mainly receives its water from rivers originating in the Aberdare Ranges and Mt. Kenya water catchment areas. Although the Aberdare National Park is a protected area (IUCN Category II), the overall catchment area has been

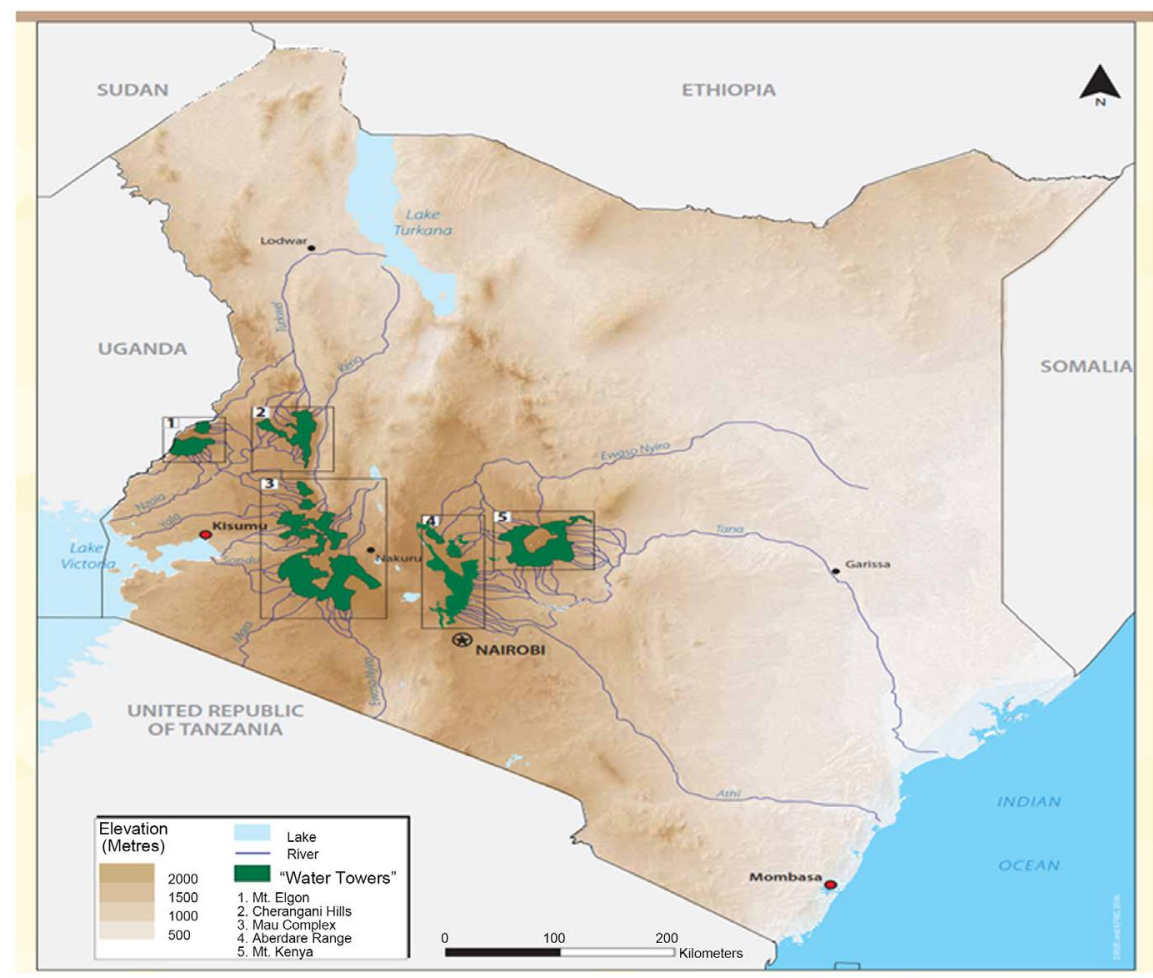

Figure 6. The five water towers of Kenya [2]. 
experiencing massive logging in the past [29]. Mombasa gets most of its water from Mzima springs which is approximately 150 Kilometers away [3]. Kisumu city remains without adequate and quality water supply to households, despite being adjacent to a fresh water lake (Lake Victoria).

Activities such as poor farming practices and deforestation lead to degradation of these water catchment areas. The consequences of catchment degradation are diverse and unpleasant i.e. it often leads to increased runoff, flash flooding, reduced infiltration, erosion and siltation just to mention but a few. Protecting the catchment environment is important for the security and sustainability of urban water supply. A healthy ecosystem guarantees that quality water is available for the cities, reducing the costs for treatment and the danger to human health.

These water towers continue to be severely damaged by: human encroachment, agricultural practices, rapid human population growth, illegal logging, charcoal burning, water pollution and over/illegal abstractions by industries and urban settlements (Figure 7).

Furthermore sharing of more than half of the rivers, lakes and aquifers with neighboring countries complicates management of these water resources because of their influence on regional security and development. Most of the water catchment areas are very attractive for agriculture hence people have encroached into these areas. For instance, in the Mau complex about 43,700 ha of the forest's protected area have severely damaged by human activities. Extreme land cover changes such as these can have serious consequences both within the forest and downstream in the form of water shortages, health risks, and desertification.

\subsection{Invasive Species}

Biotic factors are known to influence water resources. For instance, the presence of invasive species such as water hyacinth, water lettuce and various types of fish

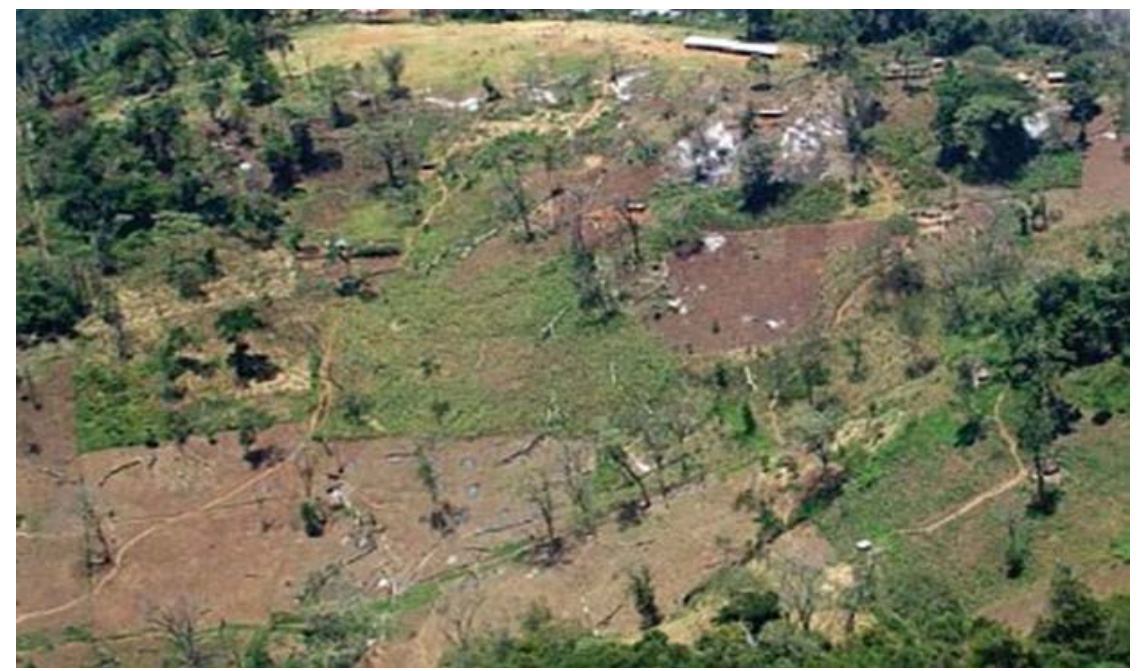

Figure 7. Degradation of the Mau forest complex by human activities-a major water catchment area in Kenya. 
bring about ecological imbalance. The proliferation of invasive plants and animal species in the main water bodies including aquatic weeds is of growing concern. Water hyacinth, fern and lettuce are degrading surface water resources, for example in Lake Victoria (Figure 8) where water hyacinth has greatly affected water drainage and supply [3].

Excess nitrogen and phosphate, the most common chemical contaminants in the world's freshwater resources [30], have contributed to the eutrophication of freshwater and coastal marine ecosystems causing degradation of major water resources [31]. These invasive species block waterways and greatly influence water quality.

In Kenya, dams play an important role in providing sustainable and reliable water supply source. Hence they are an important component in community water supply. The three big cities have their water supply systems relying on dams. In 2006, the total number of dams stood at 4102 having a storage capacity of $303,909,738 \mathrm{~m}^{3}$ [3]. Like many water bodies these dams are invaded by massive growth of water hyacinth whose rate of spread is very high due to fertilizer residue levels.

Overall, the country faces serious challenges with regard to protection of resources, provision of water supply and sanitation services. Estimates from the Water Impact Report of 2009 approximates that in 2006-2007 only 37\% of Kenyans had access to sufficient and safe drinking water close to their homes at an affordable price [32].

\section{Interventions on Water Challenges}

Despite the water challenges facing the urban populations, Kenya possesses sufficient water resources to meet demand if the available resources are properly managed. A study conducted by Camco advisory services Kenya in 2010 estimated based on water use efficiencies that, the predicted aggregate demand

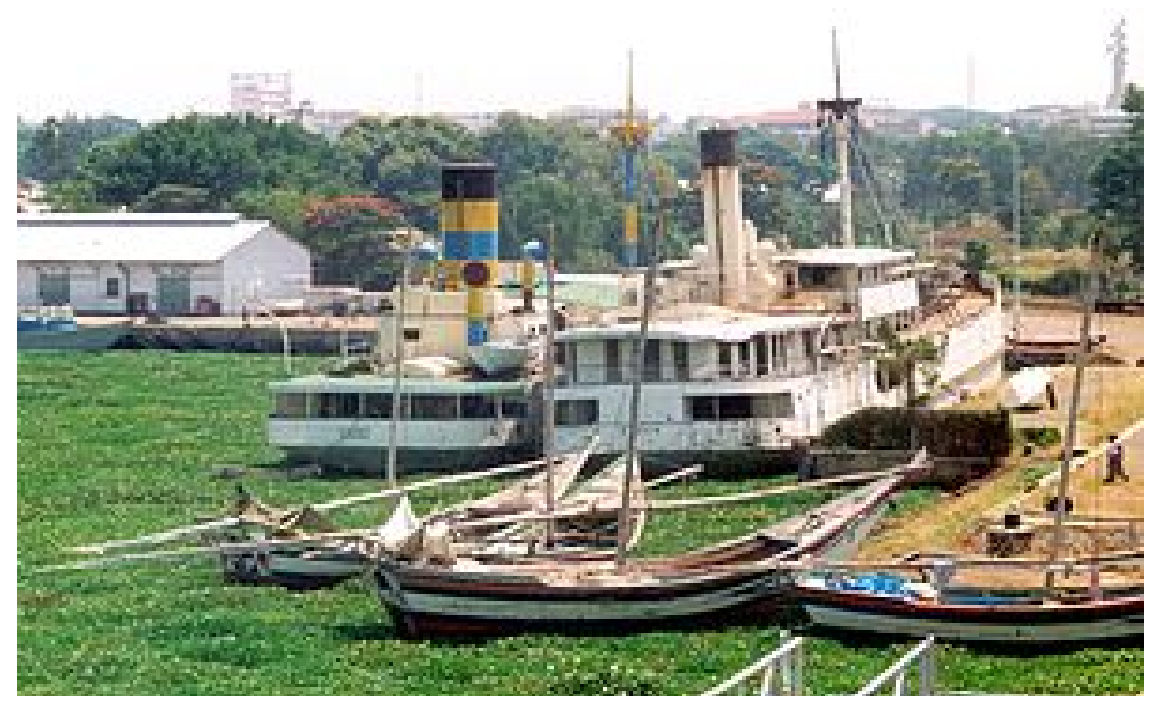

Figure 8. Kisumu bay in the shores of Lake Victoria invaded by water hyacinth. 
would rise to $5552 \mathrm{Mm}^{3}$ per year in 2020. This would remain within the country's safe yield of $8447 \mathrm{Mm}^{3}$ per yr. although the cost of supplying each additional increment of water was likely to rise sharply as the readily accessible sources continue to be tapped [33].

\subsection{Implementation of Relevant Policies}

Like many other nations, Kenya has enacted several policies at the national and regional levels to guide the conservation and management of its water resources. It set up crucial reforms in the water sector that culminated in the enactment of the Water Act of 2002 and consequent formation of various Water Resource Users Associations (WRUAs) by the Water Resource Management Authority [34] [35].

Certain responsibilities of the water management Authority were decentralized to local levels i.e. county governments and some non-governmental organizations (NGOs) were assigned to make policies, and provide and manage water resources [36] [37].

The Act vested the power to manage water resources on the Water Resource Management Authority (WRMA) which was mandated to manage water resources at the national level while the Ministry of Water and Irrigation was tasked to play an oversight and policy implementation role (Figure 9).

Water Resource Users Associations (WRUAs) were also constituted to conserve water at the local level [38]. Through the WRUAs Community based water

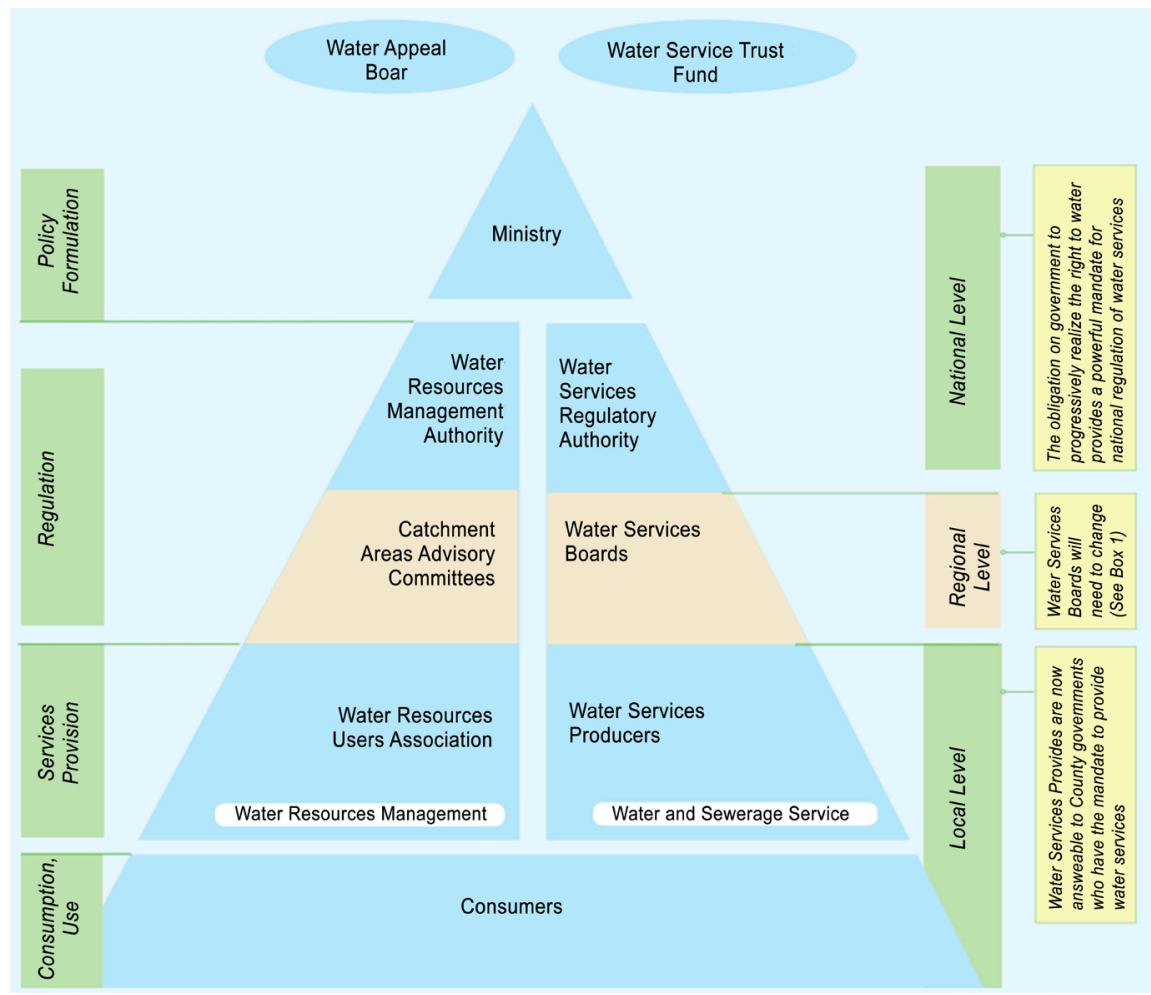

Figure 9. Implications of the new constitution on the current water sector institutional arrangements [39]. 
resource management has gained popularity in most parts of Kenya and has led to reduced illegal abstractions, reduced catchments encroachment, rehabilitation of catchment areas and river bank protection [36] [38].

A new bill was introduced in 2012 to align the Water Act of 2002 with devolution system of governance provided in the Constitution of Kenya 2010 [40] [41]. This led to the development of the National Water Master Plan 2030 [42].

\subsection{Abstraction of Underground Water}

Groundwater has become an important supplementary source in urban centers in Kenya. Harnessing of groundwater through wells/boreholes (Figure 10) is widespread but they are generally not regulated or monitored in many parts of Africa.

A well is a deep hole or channel sunk into the earth to obtain water. Like in many cities in Africa there is growing demand for ground water in the major cities in Kenya which is mainly tapped through boreholes. Nairobi depends on groundwater drawn from the Nairobi Aquifer Suite, which covers an area of approximately $3000 \mathrm{~km}^{2}$. Groundwater harnessing in Nairobi city started in the early 1950s. Reports show that in the year 2002 the city had 1350 boreholes supplying about seven thousand cubic meters per day. This accounted for $21 \%$ of the city's water supply [11]. In Kisumu, shallow hand dug wells play an important role in supplying water to the urban residents. Shallow hand dug wells are found all over the informal settlements in Kisumu and are a main or supplementary source of water for the residents. The average depth of the wells dug are about $6 \mathrm{~m}$, this is because the water table is comparatively high in the region hence making it easy to dig up the wells.

Most boreholes in the cities are operated by industrial establishments, hotels, farms in greenhouses, and private houses in some parts of the city that receive irregular supply of piped water. Groundwater is also used to supply tankers and vendors (Figure 11) that resell the water [43].

Of the over 3500 "known" boreholes located in Nairobi city, less than half have operation permits, two-thirds are unmetered, and four in five users do not pay for water. Freshwater stored in underground aquifers can effectively be used

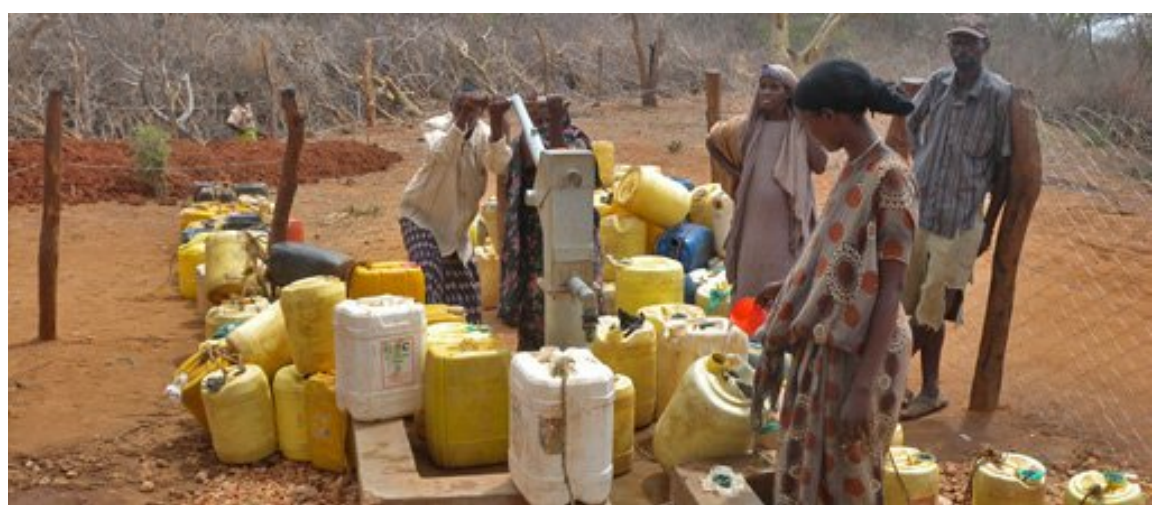

Figure 10. Residents get water into their jerry cans from a borehole using a pump. 


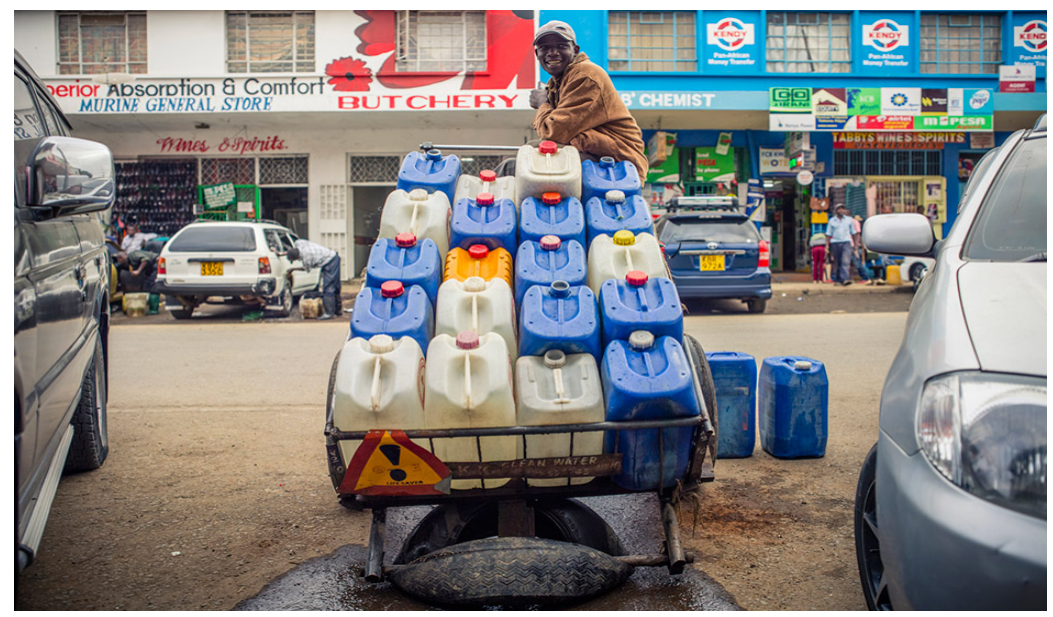

Figure 11. A water vendor with his cat supplying commercial establishments in the city using jerry cans previously filled at a water deport/storage tank/borehole.

to divert consequences of climate change e.g. in 2008/2009, Athi Water Services Board (AWSB) drilled over 40 emergency boreholes in various parts of the city and connected them to the distribution network [27].

Furthermore groundwater is known to sustain the base flows of rivers and the essential aquatic environments. The availability of groundwater resources and their replenishment rates is uncertain and this presents a serious challenge to their management and protection [44]. Hence moving forward, improved regulation and monitoring of ground water abstraction, in addition to proper management will be essential for effective and sustainable supervision of the city's available water resources.

\subsection{Establishment and Monitoring of Additional Water Kiosks}

In Nairobi city, it is reported that only about $50 \%$ of residents have access to piped water while the other half obtain water from kiosks, vendors, illegal connections or from boreholes. Moreover, only about $40 \%$ of those who have access to piped water have a 24 hour water supply daily [45].

One specific challenge in Kenyan cities has been and is still how to provide adequate and affordable water to half their population which resides in slums. From the 1970s slum residents with piped water connections have been building water kiosks (Figure 12) where they sell water to other residents in containers. Residents who have access to piped water pay relatively low water tariffs, while those who rely on water sold in cans through water kiosks have to part with much more.

Inconsistent pricing in the kiosks remains a challenge since prices do fluctuate depending on availability and catastrophes like droughts. Hence prices have become difficult to regulate for instance, in 1996 the water department of the then municipal council of Nairobi (presently Nairobi County Government) recommended a resale price, but could not enforce it so the poorest ended up paying much more than those having piped water in their houses [47]. 


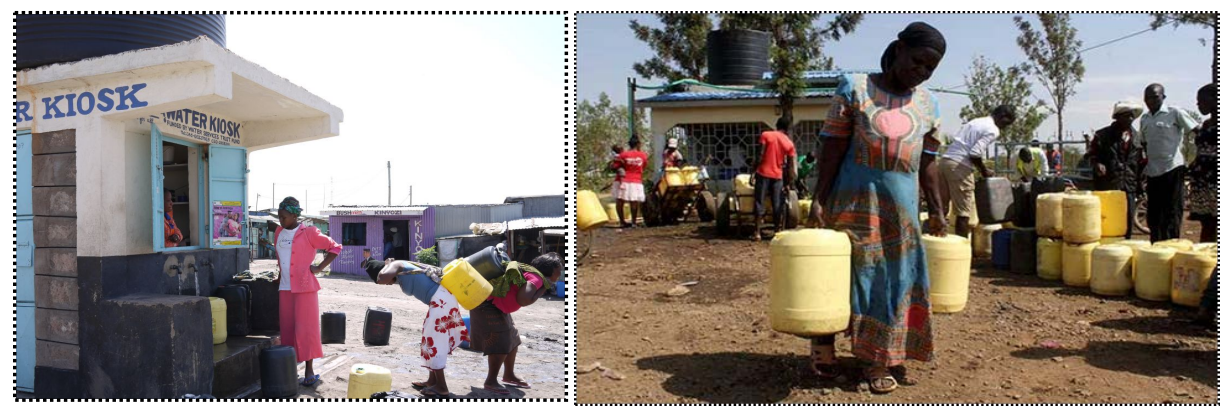

Figure 12. Water kiosk [46].

\subsection{Rain Water Harvesting}

Inadequate water harvesting is responsible for the regional imbalance in water security with some parts of the country having a lot of water during rainy seasons and little or no water during dry periods. The challenges are further compounded by extreme climatic changes that cause flooding and immense negative impact on both the social and economic fronts.

Sub-Saharan Africa has a plenty supply of rainwater, but it is not evenly distributed and highly seasonal. Kenya in particular experiences droughts and floods in every three to four years. It receives rainfall that varies between less than $200 \mathrm{~mm}$ in the dry parts to over $1800 \mathrm{~mm}$ in its highlands around Mount Kenya [48]. Kenya's renewable freshwater resources varies significantly depending on time and regions and cannot adequately sustain the ever growing demand in the major cities.

Rain water harvesting could offer a supplementary means of mitigating the challenges of drought, water scarcity and depletion of water resources. Surface water is scarce and exploitation of groundwater is not economically feasible. Therefore, sustainable rain water catchment systems remain mainly one of the most attractive solution to water scarcity. However rainwater harvesting for domestic use in the cities is not viable owing to the housing plans and designs as well as air pollution associated with many industrial establishments and motor vehicle emissions. However, if rainwater could be harnessed and treated before use, it could offer a solution to the perennial water shortages currently witnessed.

\subsection{Construction of Additional Dams}

The Kenyan government under the Ministry of Environment, Water and Natural Resources has initiated projects aimed at increasing the number of water storage dams to avert the consequences of water shortage. By 2013, the ministry had completed the construction of three additional storage dams namely; Chemususu and Kiserian Dams with water capacity of 11.5 million $\mathrm{m}^{3}$ and 1.2 million $\mathrm{m}^{3}$ respectively. Other projects undertaken by the ministry included the construction of Rahole Canal in Garrisa County and the Nyeri Water Treatment Plant among others [49]. 


\subsection{Reclamation of Water Catchment Areas}

Deforestation in Kenya's water towers is reported to be depriving economy of about 6 billion Shillings annually and this threatens the country's water supply by more than $70 \%$ [50]. Several national organizations have been formed to help restore the water towers i.e. the Mount Kenya Environmental Conservation (MKEC) program which has been involved in establishing tree nurseries to be used for rehabilitating the Mt. Kenya water tower (Figure 13(a)).

In the effort to conserve the Kenyan water towers an initiative dabbed "one tree at a time' was coined in 2014 through a partnership between the Serena hotels, lions international, Kenya defense forces, Kenya girl guides association, Nairobi Water and Sewerage Company. This initiative was aimed at planting 25,000 seedlings at the Chania falls, $7 \mathrm{~km}$ from Ndakaini dam which is the main supplier of water to Nairobi city (Figure 13(b)).

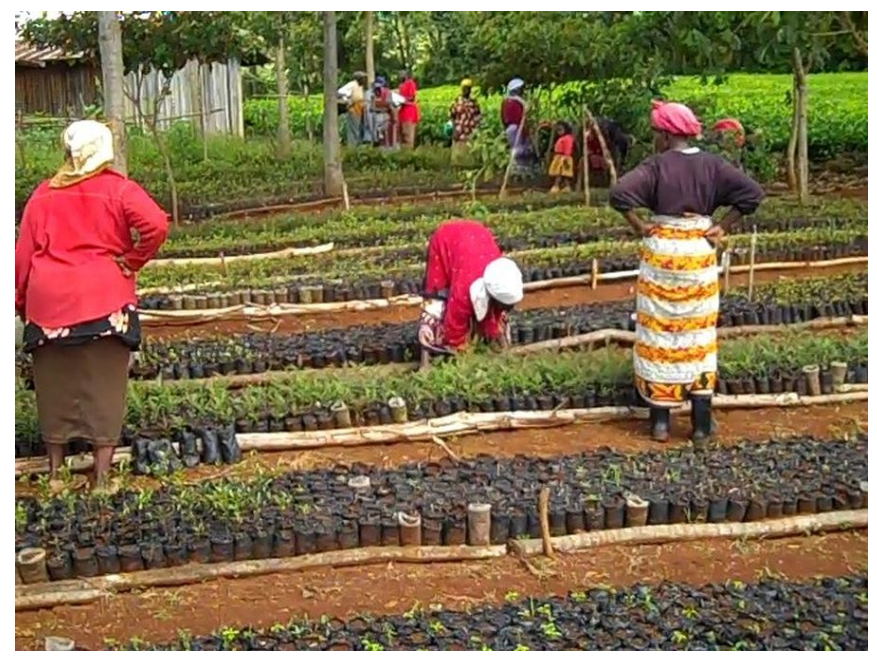

(a)

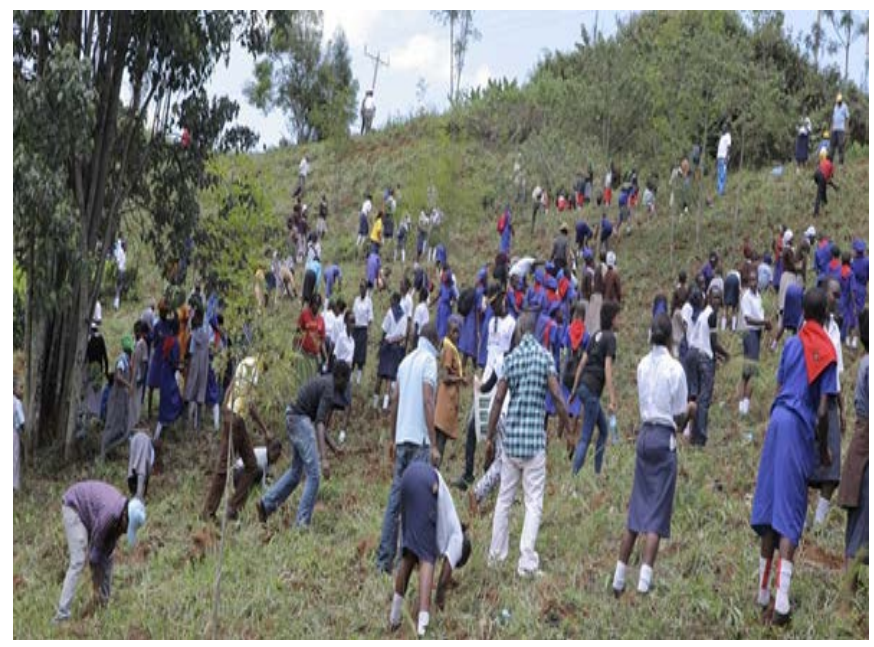

(b)

Figure 13. (a) Environmental Conservation program establishing tree nurseries; (b) Lions International, Kenya Defense Forces, Kenya Girl Guides Association and Nairobi Water and Sewerage Companyplant trees around Ndakaini dam [51]. 


\section{Strategies to Reduce Water Scarcity}

Based on present water demand and future national development plans, it is possible that Kenya, like many nations in the world could face a huge gap between water demand and the available water supply in the years to come. Sustainable development and management of the water resources is therefore critical and should effectively be addressed by respective government institutions, various development partners, civil society groups and the private sectors.

Kenya for instance, could boost its water productivity in short term by harmonizing and strengthening the already established multi-level water management bodies such as the Catchment Area Advisory Committees (CAAC), Water Users Associations (WUAs) and Water Resource Management Authority (WRMA). To improve the availability of sustainable water supply, conservation and restoration of the national water catchment areas as well as strategic investment in additional dams is key. The additional dams would help increase water storage capacity for long term uses and to avert recurrent disasters such as drought. In addition, construction of efficient water treatment plants should be prioritized by the urban water and sewerage companies to facilitate water treatment and re-use.

Alignments of the current water sector institutions need to be made in order to fit to the requirements of the New Constitution that was promulgated in 2010 after passing the water amendment act of 2002. The new constitution places the responsibility of providing safe and clean water to the state and its agents. In the new constitution under the bill of rights, it is clear that the National and County levels of government have a responsibility to provide clean water in adequate quantities.

\section{Conclusions}

The high urbanization rate in Africa as a whole has not been matched with service delivery. Many of its cities are experiencing difficulties in supplying the growing number of occupants with adequate water services. The demand for adequate and clean water supply is rising due to the swelling population, and in response to the global obligation to meet the Millennium Development Goals [18]. Africa's urban residents without better drinking water increased from 29 million to 57 million between 1990 and 2008 [52].

Kenya suffers from a chronic water crisis due to various causes among them droughts, forest degradation, floods, lack of proper water management strategies, water contamination and unprecedented population growth. While problems like forest degradation, poor water management and contamination of water are possibly solvable, the frequency and severity of droughts and floods is attributable to the ongoing climatic change which is likely to become more unpredictable in the future. Environmental pollution could also greatly influence the capacity to provide adequate and quality drinking water to any population. Hence to safeguard water safety, there is need to focus on source protection, 
wiser use of fertilizer and pesticides, reducing domestic and industrial pollution as fundamental components of complete water management strategy.

\section{Acknowledgements}

The authors wish to thank Karatina University and Jomo Kenyatta University of Agriculture and Technology for their invaluable support in the preparation of this manuscript.

\section{Conflicts of Interest}

The authors declare no conflicts of interest regarding the publication of this paper.

\section{References}

[1] Kenya Census (2009).

[2] Government of Kenya (GoK) (2007) Kenya Aims to Be a Nation Living in a Clean, Secure and Sustainable Environment by 2030, Kenya Vision 2030.

[3] UN World Water Development Report (2006) 2nd UN World Water Development Report.

[4] UNHABITAT Report 2010. The State of African Cities.

[5] Mungai, D.N. and Owour, S.O. (2014) Urbanization, Water and Ecosystems: The Case of Nairobi, GRID-Arendal.

[6] WWF Report 2011, Big Cities. Big Water. Big Challenges. Water in an Urbanizing World.

[7] http://www.nairobiwater.co.ke

[8] Nairobi County Water and Sewerage Company Ltd (NCWSC) (2010) Draft Strategic Plan for the Period 2010/11 to 2014/15. Nairobi City Water and Sewerage Company, Nairobi.

[9] The World Factbook. https://www.cia.gov/library/publications/the-world-factbook/index

[10] Business Daily, Retrieved July 2017.

[11] Mogaka, H. (2006) Climate Variability and Water Resources Degradation in Kenya: Improving Water Resources Development and Management (Vol. 69). World Bank Publications.

[12] Henninger, N. and Landsberg, F. (2007) Nature's Benefits in Kenya, an Atlas of Ecosystems and Human Well-Being, World Resources Institute, 164.

[13] Sustainable Water and Sanitation in Africa (Suwasa) USAID Final Report November 2015.

[14] KIWASCO, 2007.

[15] Wagah, G.G., Onyango, G.M. and Kibwage, J.K. (2010) Accessibility of Water Services in Kisumu Municipality. Journal of Geography and Regional Planning, 3, 114-125.

[16] LVSWSB (2008) Long-Term Action Plan: Sewerage Design Report. Lake Victoria South Water Services Board (LVSWSB), Kisumu.

[17] UN-Habitat (2008) The State of African Cities 2008. UN-Habitat, Naiorbi.

[18] Ngayu, M. (2011) Sustainable Urban Communities: Challenges and Opportunities 
in Kenya's Urban Sector. International Journal of Humanities and Social Science, 1. http://www.ijhssnet.com

[19] CBS Population Census 1999.

[20] UN World Water Day Report (2011) Water in an Urbanizing World.

[21] Carr, G.M. and Neary, J.P. (2008) Water Quality for Ecosystem and Human Health. 2nd Edition, DS 10 at UC Berkeley.

[22] Mayers, J., Batchelor, C., Bond, I., Hope, R.A., Morrison, E. and Wheeler, B. (2009) Water Ecosystem Services and Poverty under Climate Change: Key Issues and Research Priorities. Natural Resource Issues No. 17, International Institute for Environment and Development, London.

[23] UNEP (2010) Annual Report.

[24] UNESCO (2003) Water for People, Water for Life, World Water Assessment Programme. http://www.google.co.ke/books

[25] Water Hackathon: Water Problems in Nairobi.

[26] Water Services Regulatory Board Impact Report 2011. A Performance Report of Kenya's Water Services Sector.

[27] Jambo Nairobi. Water Supply to Nairobi.

[28] Republic of Kenya (ROK) Forestry Policy, 2014.

[29] Dudley, N. and Stolton, S. (2003) The Importance of Forest Protected Areas to Drinking Water. World Bank/WWF Alliance for Forest Conservation and Sustainable Use.

[30] WWAP World Water Assessment Plan, 2009.

[31] UN-Water, 2013.

[32] IFAD (2012) Terminal Evaluation of IFAD-GEF Project ID 1848. MKEPP.

[33] Stephen, M., Samuel, M., Peterson, O. and Kristen, W. (2010) Camco Advisory Services Kenya Ltd.

[34] Yerian, S., Hennink, M., Greene, L.E., Kiptugen, D. and Buri, J. (2014) The Role of Women in Water Management and Conflict Resolution in Marsabit, Kenya. Environmental Management, 54, 1320-1330. https://doi.org/10.1007/s00267-014-0356-1

[35] Baldwin, E., Washington-Ottombre, C., Dell'Angelo, J., Cole, D. and Evans, T. (2015) Polycentic Governance and Irrigation Reform in Kenya. Governance, Kenya.

[36] K'akumu, O.A., Olima, W.H. and Opiyo, R.O. (2016) Local Experiences in Irrigation Management Transfer (Imt): The Case of the West Kano Scheme in Kenya.

[37] McCord, P., Dell'Angelo, J., Baldwin, E. and Evans, T. (2016) Polycentric Transformation in Kenyan Water Governance: A Dynamic Analysis of Institutional and Social-Ecological Change. Policy Studies Journal, 45, 633-658.

[38] Mathenge, J.M., Luwesi, C.N., Shisanya, C.A., Mahiri, I. and Akombo, R.A. (2014) Water Security Where Governmental Policies Conflict with Local Practices: The Roles of Community Water Management Systems in Ngaciuma-Kinyaritha, Kenya. International Journal of Innovative Research and Development, 3, 793-804.

[39] Chris, H., Patrick, M. and Eberhard, R. (2013) Devolution in Kenya: Opportunities and Challenges for the Water Sector.

[40] Government of Kenya (GOK) (2010) The Constitution of Kenya, 2010. Kenya Law.

[41] Government of Kenya (GOK) (2014) The Water Bill, 2014 (Draft Bill Introduced into Parliament for Approval).

http://kenyalaw.org/kl/fileadmin/pdfdownloads/bills/2014/WaterBill2014.pdf 
[42] JICA (Japanese International Cooperation Agency) and GOK Government of Kenya (2013) The Development of the National Water Master Plan 2030 (Final Draft). Nippon Koei, Nairobi.

[43] World Bank Groundwater Management (GWMATE) (2011) Sustainable Groundwater Management: Concepts and Tools GWMATE Briefing Note Series Sustainable Groundwater Management Lessons from Practice.

[44] Van der, G.J. (2012) Groundwater and Global Change: Trends, Opportunities and Challenges. UNESCO Publishing, Paris.

[45] Nairobi Water Company Profile, 2017.

[46] https://www.eawag.ch/en/department/ess/projects/ehpsy-water-kiosk-kenya/

[47] Skytta, T. and Landeau, J.-F. (1996) World Bank Operations Evaluation Department. Report No. 15586, Development of Housing, Water Supply, and Sanitation, Nairobi.

[48] Aquastat Country Profile Kenya. 1.

[49] Kyengo, K. (2013) Ministry of Environment, Water and Natural Resources State Department for Water Kenya-Spain Multi-Lateral Partnership Meeting 10th December 2013.

[50] Kenya Water Towers, Forests and Green Economy. Report of the High-Level National Dialogue on 5-7th November 2012.

[51] http://www.mod.go.ke/?p=5537

[52] WHO/UNICEF, 2010. 